\title{
Hosoya Polynomials of The Width Distance of Some Cog-Special Graphs
}

Tahir H. Ismail

Tahir_hs@yahoo.com
Ahmed M. Ali

ahmedgraph@uomosul.edu.iq

College of Computer Sciences and Mathematics

University of Mosul, Mosul, Iraq

Received on: 29/03/2011

Accepted on: 21/06/2011

ABSTRACT

In this paper, we give some definitions and properties of the width distance and find the Hosoya polynomials, Wiener indices, and the average distances of some special cog-graphs with respect to the width distance.

Keyword: Width distance, Hosoya polynomial, Wiener index, average distance, coggraphs.

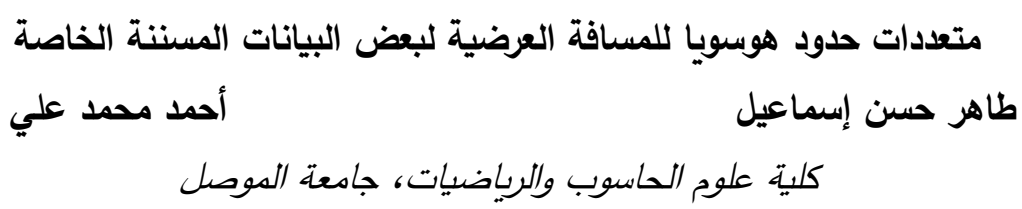

تاريخ قبول البحث: 2011/06/21

تاريخ استلام البحث: 2011/03/29

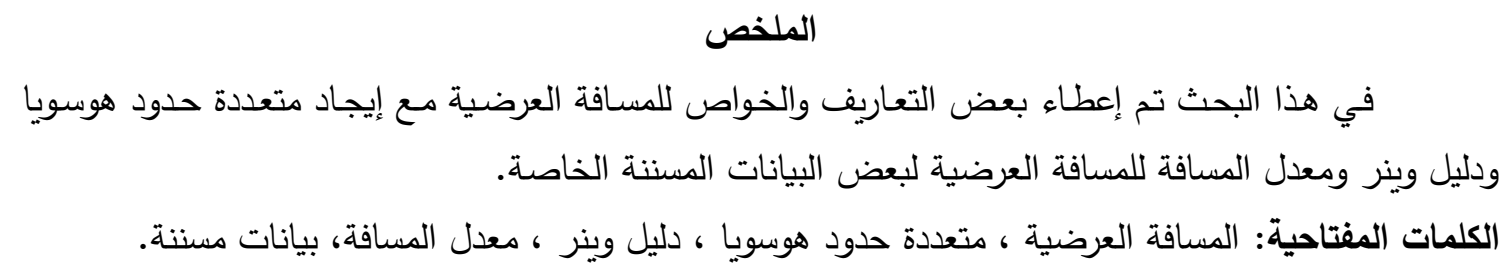

\section{Introduction:}

Because of the development of parallel architectures for interconnection computer networks, there has recently been interest in generalizations of the distance concept, for examples, the n-distance [1], Steiner distance [5], and width distance [2].

In [2] A. S. Aziz obtained Hosoya polynomials of the width distance of some special graphs and some compound graphs. It would be interesting to compute this polynomial for various graphs and to study its properties. It would also be interesting to see if this object yields any useful information in chemistry, group theory, or computer science. For more information about these concepts and their relation to networks, see the article of Hsu [6].

Let $\mathrm{u}$ and $\mathrm{v}$ be any two distinct vertices in a connected graph $\mathrm{G}$, define the container $\mathrm{C}(\mathrm{u}, \mathrm{v})$ as a set of vertex-disjoint paths between vertices $\mathrm{u}$ and $\mathrm{v}$, i.e., any two paths in $C(u, v)$ have only $u$ and $v$ in common. The container width $w=w(C(u, v))$, is the number of paths in the container, i.e., $\mathrm{w}(\mathrm{C}(\mathrm{u}, \mathrm{v}))=|\mathrm{C}(\mathrm{u} . \mathrm{v})|$. The length of a container $l=l(\mathrm{C}(\mathrm{u}, \mathrm{v}))$ is the length of the longest path in $\mathrm{C}(\mathrm{u}, \mathrm{v})$. For a fixed positive integer $\mathrm{w}$, define the width distance (w-distance) between $u$ and $v([2],[7])$ as:

$$
\mathrm{d}_{\mathrm{w}}^{*}(\mathrm{u}, \mathrm{v} \mid \mathrm{G})=\min _{\mathrm{C}(\mathrm{u}, \mathrm{v})} l(\mathrm{C}(\mathrm{u}, \mathrm{v})),
$$

where the minimum is taken over all containers $\mathrm{C}(\mathrm{u}, \mathrm{v})$ of width $\mathrm{w}$. We may denote the width distance between any two distinct vertices $u$ and $v$ in $G$ by $d_{w}^{*}(u, v)$ if there is no confusion. 
Note that when $\mathrm{w}=1$, then $\mathrm{d}_{\mathrm{w}}^{*}(\mathrm{u}, \mathrm{v})$ reduces to the usual distance between vertices $\mathrm{u}$ and $\mathrm{v}$ which denoted by $\mathrm{d}(\mathrm{u}, \mathrm{v})([4],[7])$. Therefore, in this paper, we take $2 \leq \mathrm{w} \leq \mathrm{k}_{0}$, in which $\mathrm{k}_{0}$ is the connectivity of $\mathrm{G}[3]$.

To define the diameter and radius of any connected graph $G$ with respect to the width distance, we first define the eccentricity.

The w-eccentricity $e_{w}^{*}(v)$ of the vertex $v$ in a graph $G$ is the greatest possible wdistance from $v$ to all other vertices of $G$, that is

$$
\mathrm{e}_{\mathrm{w}}^{*}(\mathrm{v})=\max _{\mathrm{u} \in \mathrm{V}(\mathrm{G})}\left\{\mathrm{d}_{\mathrm{w}}^{*}(\mathrm{u}, \mathrm{v})\right\} \text {. }
$$

The w-diameter $\delta_{\mathrm{w}}^{*}=\delta_{\mathrm{w}}^{*}(\mathrm{G})$ of $\mathrm{G}$ is defined by

$$
\delta_{\mathrm{w}}^{*}(\mathrm{G})=\operatorname{diam}_{\mathrm{w}}^{*} \mathrm{G}=\max _{\mathrm{v} \in \mathrm{V}(\mathrm{G})} \mathrm{e}_{\mathrm{w}}^{*}(\mathrm{v})=\max _{\mathrm{v}, \mathrm{u} \in \mathrm{V}(\mathrm{G})}\left\{\mathrm{d}_{\mathrm{w}}^{*}(\mathrm{u}, \mathrm{v})\right\} .
$$

The minimum w-distance $\mathrm{m}_{\mathrm{w}}=\mathrm{m}_{\mathrm{w}}(\mathrm{G})$ of $\mathrm{G}$ is defined by

$$
\mathrm{m}_{\mathrm{w}}(\mathrm{G})=\min _{\mathrm{u}, \mathrm{v} \in \mathrm{V}(\mathrm{G})}\left\{\mathrm{d}_{\mathrm{w}}^{*}(\mathrm{u}, \mathrm{v})\right\} \text {. }
$$

The w-radius $r_{\mathrm{w}}^{*}=\mathrm{r}_{\mathrm{w}}^{*}(\mathrm{G})$ of $\mathrm{G}$ is defined by

$$
r_{\mathrm{w}}^{*}(G)=\operatorname{rad}_{\mathrm{w}}^{*} \mathrm{G}=\min _{\mathrm{v} \in \mathrm{V}(\mathrm{G})} \mathrm{e}_{\mathrm{w}}^{*}(\mathrm{v}) \text {. }
$$

A vertex $v$ in $G$ is said to be w-central vertex if $e_{w}^{*}(v)=\operatorname{rad}_{w}^{*} G$, a graph $G$ may contain more than one w-centeral vertex, we define the w-center of a graph $\mathbf{G}$, $\mathrm{Z}_{\mathrm{w}}^{*}(\mathrm{G})$, as the set of all w-central vertices of $\mathrm{G}$.

It is clear that the w-distance in connected graphs does not satisfy the metric axioms, because for $\mathrm{w} \geq 2, \mathrm{~d}_{\mathrm{w}}^{*}(\mathrm{u}, \mathrm{v}) \geq 2, \mathrm{~d}_{\mathrm{w}}^{*}(\mathrm{u}, \mathrm{v})=\mathrm{d}_{\mathrm{w}}^{*}(\mathrm{v}, \mathrm{u})$, but $\mathrm{d}_{\mathrm{w}}^{*}(\mathrm{u}, \mathrm{y})+\mathrm{d}_{\mathrm{w}}^{*}(\mathrm{y}, \mathrm{v}) \geq \mathrm{d}_{\mathrm{w}}^{*}(\mathrm{u}, \mathrm{v})$ is not satisfactory for all vertices $\mathrm{u}$ and $\mathrm{v}$ of $\mathrm{G}$. To show that, we take the next example .

Example: Let $\mathrm{G}$ be a graph of order 10 and size 12, as shown in Fig.1.1.

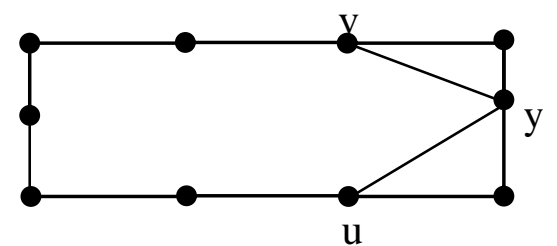

Fig. 1.1.

We notice that $d_{2}^{*}(v, y)=2=d_{2}^{*}(u, y)$, but $d_{2}^{*}(u, v)=6$, so $\mathrm{d}_{2}^{*}(\mathrm{u}, \mathrm{y})+\mathrm{d}_{2}^{*}(\mathrm{y}, \mathrm{v})<\mathrm{d}_{\mathrm{w}}^{*}(\mathrm{u}, \mathrm{v})$.

Moreover, it is clear that for all connected graphs $\mathrm{G}$

- $\delta_{\mathrm{w}}^{*}(\mathrm{G}) \geq \delta(\mathrm{G})$, where $\delta(\mathrm{G})$ is diameter of $\mathrm{G}$.

- $r_{w}^{*}(G) \geq r(G)$, where $r(G)$ is radius of $G$.

Equality holds if $\mathrm{w}=1$.

Concerning the width minimum distance $\mathrm{m}_{2}(\mathrm{G})$, we have

- $\mathrm{m}_{2}(\mathrm{G})=2$ iff $\mathrm{G}$ contains a triangle or a cycle of order 4 . 


\section{Hosoya Polynomial of The Width Distance}

Let $\mathrm{G}$ be a connected graph of order $\mathrm{p}$, size $\mathrm{q}$, and let $\mathrm{w}$ be a fixed positive integer such that $2 \leq \mathrm{w} \leq \mathrm{k}_{0}$, and w-diameter is $\delta_{\mathrm{w}}^{*}$. The Wiener index of the wdistance (w-Wiener index) is the sum of all w-distances in G, that is [2]

$$
\mathrm{W}_{\mathrm{w}}^{*}(\mathrm{G})=\sum_{\mathrm{u}, \mathrm{v} \in \mathrm{V}(\mathrm{G})} \mathrm{d}_{\mathrm{w}}^{*}(\mathrm{u}, \mathrm{v}), \mathrm{u} \neq \mathrm{v} .
$$

The Hosoya polynomial with respect to the width distance function $\mathrm{d}_{\mathrm{w}}^{*}$ (called w-Hosoya polynomial) is defined by [2]:

$$
\mathrm{H}_{\mathrm{w}}^{*}(\mathrm{G} ; \mathrm{x})=\sum_{\mathrm{u}, \mathrm{v} \in \mathrm{V}(\mathrm{G})} \mathrm{x}^{\mathrm{d}_{\mathrm{w}}^{*}(\mathrm{u}, \mathrm{v})} \text {. }
$$

If $\mathrm{C}_{\mathrm{w}}^{*}(\mathrm{G}, \mathrm{k})$ is the number of unordered pairs of distinct vertices that has $\mathrm{k}$ w-distance apart, $\mathrm{m}_{\mathrm{w}} \leq \mathrm{k} \leq \delta_{\mathrm{w}}^{*}$, then

$$
\mathrm{H}_{\mathrm{w}}^{*}(\mathrm{G} ; \mathrm{x})=\sum_{\mathrm{k}=\mathrm{m}_{\mathrm{w}}}^{\delta_{\mathrm{w}}^{*}} \mathrm{C}_{\mathrm{w}}^{*}(\mathrm{G}, \mathrm{k}) \mathrm{x}^{\mathrm{k}},
$$

If $\mathrm{w} \geq 2$, then $\mathrm{w}$-distance is not less than $2,\left(\mathrm{~d}_{\mathrm{w}}^{*}(\mathrm{u}, \mathrm{v}) \geq 2, \mathrm{w} \geq 2\right)$.

It is clear that

$$
\mathrm{W}_{\mathrm{w}}^{*}(\mathrm{G})=\left.\frac{\mathrm{d}}{\mathrm{dx}} \mathrm{H}_{\mathrm{w}}^{*}(\mathrm{G} ; \mathrm{x})\right|_{\mathrm{x}=1}=\sum_{\mathrm{k}=\mathrm{m}_{\mathrm{w}}}^{\delta_{\mathrm{w}}^{*}} \mathrm{kC}_{\mathrm{w}}^{*}(\mathrm{G}, \mathrm{k}),
$$

The average $w$-distance, $\mu_{\mathrm{w}}^{*}(\mathrm{G})$, of $\mathrm{G}$ is defined as :

$$
\mu_{\mathrm{w}}^{*}(\mathrm{G})=\mathrm{W}_{\mathrm{w}}^{*}(\mathrm{G}) /\left(\begin{array}{l}
\mathrm{p} \\
2
\end{array}\right),
$$

We define the w-Hosoya polynomial of a vertex $\mathrm{v}$ in $\mathrm{G}$ as :

$$
\mathrm{H}_{\mathrm{w}}^{*}(\mathrm{v}, \mathrm{G} ; \mathrm{x})=\sum_{\mathrm{k}=\mathrm{m}_{\mathrm{w}}}^{\delta_{\mathrm{w}}^{*}} \mathrm{C}_{\mathrm{w}}^{*}(\mathrm{v}, \mathrm{G}, \mathrm{k}) \mathrm{x}^{\mathrm{k}} \text {, for } 2 \leq \mathrm{w} \leq \mathrm{k}_{0} .
$$

where $C_{w}^{*}(v, G, k)$ is the number of vertices in $V(G)-\{v\}$ that are at w-distance $k$ from vertex $\mathrm{v}$. We note that

$$
\sum_{\mathrm{v} \in \mathrm{V}(\mathrm{G})} \mathrm{C}_{\mathrm{w}}^{*}(\mathrm{v}, \mathrm{G}, \mathrm{k})=2 \mathrm{C}_{\mathrm{w}}^{*}(\mathrm{G}, \mathrm{k}) \text {, for } \mathrm{m}_{\mathrm{w}} \leq \mathrm{k} \leq \delta_{\mathrm{w}}^{*} \text {, and } 2 \leq \mathrm{w} \leq \mathrm{k}_{0} \text {. }
$$

From the previous discussion, we note that

$$
\sum_{\mathrm{v} \in \mathrm{V}(\mathrm{G})} \mathrm{H}_{\mathrm{w}}^{*}(\mathrm{v}, \mathrm{G} ; \mathrm{x})=2 \mathrm{H}_{\mathrm{w}}^{*}(\mathrm{G} ; \mathrm{x}) \text {. }
$$

Let $\mathrm{S}$ be a nonempty subset of $\mathrm{V}(\mathrm{G})$, then define

$$
\mathrm{H}_{\mathrm{w}}^{*}(\mathrm{~S} ; \mathrm{x})=\sum_{\mathrm{v} \in \mathrm{S}} \mathrm{H}_{\mathrm{w}}^{*}(\mathrm{v} ; \mathrm{G} ; \mathrm{x}) \text {, }
$$

Moreover, we define $\mathrm{C}_{\mathrm{w}}^{*}(\widetilde{\mathrm{S}}, \mathrm{G}, \mathrm{k})$ as the number of pairs $\{\mathrm{u}, \mathrm{v}\}$ of vertices of $\mathrm{S}$ such that $\mathrm{d}_{\mathrm{w}}^{*}(\mathrm{u}, \mathrm{v} \mid \mathrm{G})=\mathrm{k}$, therefore we define $\mathrm{H}_{\mathrm{w}}^{*}(\tilde{\mathrm{S}}, \mathrm{G} ; \mathrm{x})=\sum_{\mathrm{k}=2} \mathrm{C}_{\mathrm{w}}^{*}(\tilde{\mathrm{S}}, \mathrm{G}, \mathrm{k}) \mathrm{x}^{\mathrm{k}}$.

Finally, if $T_{1}, T_{2}, \ldots, T_{r}$ is a partition of $V(G)$, then 


$$
2 \mathrm{H}_{\mathrm{w}}^{*}(\mathrm{G} ; \mathrm{x})=\sum_{\mathrm{i}=1}^{\mathrm{r}} \mathrm{H}_{\mathrm{w}}^{*}\left(\mathrm{~T}_{\mathrm{i}} ; \mathrm{G} ; \mathrm{x}\right) \text {. }
$$

\section{On The Coefficients of The w-Hosoya Polynomial}

If $\mathrm{H}_{\mathrm{w}}^{*}(\mathrm{G} ; \mathrm{x})=\sum_{\mathrm{k}=\mathrm{m}_{\mathrm{w}}}^{\delta_{\mathrm{w}}^{*}(\mathrm{G})} \mathrm{C}_{\mathrm{w}}^{*}(\mathrm{G}, \mathrm{k}) \mathrm{x}^{\mathrm{k}}, 2 \leq \mathrm{w} \leq \mathrm{k}_{0}$ is the $\mathrm{w}$-Hosoya polynomial of $\mathrm{a}$ connected graph $G$ for a fixed $w$, then the sequence of a graph $G$ invariant $\left\{\mathrm{C}_{\mathrm{w}}^{*}(\mathrm{G}, \mathrm{k})\right\}_{\mathrm{k}=\mathrm{m}_{\mathrm{w}}}^{\delta_{\mathrm{w}}^{*}(\mathrm{G})}$, for a fixed $\mathrm{w}, 2 \leq \mathrm{w} \leq \mathrm{k}_{0}$, often possesses some distinguished properties.

1. The polynomial $\mathrm{H}_{\mathrm{w}}^{*}(\mathrm{G} ; \mathrm{x})$ is called unimodal if , for some index $\mathrm{h}$, $\mathrm{C}_{\mathrm{w}}^{*}\left(\mathrm{G}, \mathrm{m}_{\mathrm{w}}\right) \leq \mathrm{C}_{\mathrm{w}}^{*}\left(\mathrm{G}, \mathrm{m}_{\mathrm{w}}+1\right) \leq \mathrm{C}_{\mathrm{w}}^{*}\left(\mathrm{G}, \mathrm{m}_{\mathrm{w}}+2\right) \leq \ldots \leq \mathrm{C}_{\mathrm{w}}^{*}(\mathrm{G}, \mathrm{h}) \geq \mathrm{C}_{\mathrm{w}}^{*}(\mathrm{G}, \mathrm{h}+1) \geq \ldots \geq \mathrm{C}_{\mathrm{w}}^{*}\left(\mathrm{G}, \delta_{\mathrm{w}}^{*}(\mathrm{G})\right),(3.1)$ and it is strong-unimodal if (3.1) holds without equalities.

For example, [2] : If $\mathrm{G}=\mathrm{k}_{2} \times \mathrm{P}_{\mathrm{m}}$ is the graph as shown in Fig. 3.1, then
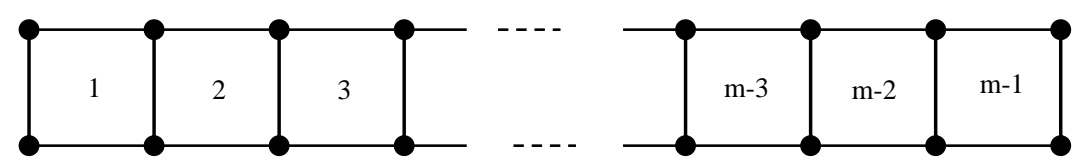

Fig. 3.1. G

$$
\mathrm{H}_{2}^{*}(\mathrm{G} ; \mathrm{x})=2(\mathrm{~m}-1) \mathrm{x}^{2}+(5 \mathrm{~m}-6) \mathrm{x}^{3}+2 \sum_{\mathrm{i}=2}^{\mathrm{m}-1}[2 \mathrm{~m}-2 \mathrm{i}-1] \mathrm{x}^{\lceil(2 \mathrm{i}+3) / 2\rceil},
$$

is strong-unimodal at index $\mathrm{h}=3$.

2. The polynomial $H_{w}^{*}(G ; x)$ is called palindromic if

$$
\mathrm{C}_{\mathrm{w}}^{*}(\mathrm{G}, \mathrm{k})=\mathrm{C}_{\mathrm{w}}^{*}\left(\mathrm{G}, \delta_{\mathrm{w}}^{*}(\mathrm{G})-\mathrm{k}\right), \text { for } \mathrm{m}_{\mathrm{w}} \leq \mathrm{k} \leq \delta_{\mathrm{w}}^{*}(\mathrm{G}),
$$

and it is $\mathbf{j}$-semi-palindromic if (4.2) holds for $\mathrm{k}=\mathrm{m}_{\mathrm{w}}+\mathrm{j}, \mathrm{m}_{\mathrm{w}}+\mathrm{j}+1, \ldots, \delta_{\mathrm{w}}^{*}(\mathrm{G})-\mathrm{j}$, for some $\mathrm{j} \geq 1$.

For example, [2]: If $\mathrm{C}_{\mathrm{p}}$ is a cycle of order $\mathrm{p}, \mathrm{p} \geq 3$, then

$$
\mathrm{H}_{2}^{*}\left(\mathrm{C}_{\mathrm{p}} ; \mathrm{x}\right)=\left[\begin{array}{l}
\mathrm{p}\left(\mathrm{x}^{(\mathrm{p}+1) / 2}+\mathrm{x}^{(\mathrm{p}+3) / 2}+\ldots+\mathrm{x}^{\mathrm{p}-2}+\mathrm{x}^{\mathrm{p}-1}\right), \text { if } \mathrm{p} \text { is odd }, \\
\mathrm{p}\left(\mathrm{x}^{\mathrm{p} / 2}+\mathrm{x}^{\mathrm{p} / 2+1}+\ldots+\mathrm{x}^{\mathrm{p}-2}+\mathrm{x}^{\mathrm{p}-1}\right) \text {, if } \mathrm{p} \text { is even. }
\end{array}\right.
$$

is palindromic if $\mathrm{p}$ is odd, and it is 1-semi-palindromic if $\mathrm{p}$ is even.

3. The polynomial $\mathrm{H}_{\mathrm{w}}^{*}(\mathrm{G} ; \mathrm{x})$ is called monotonically increasing (or monotonically decreasing $)$ if $\mathrm{C}_{\mathrm{w}}^{*}(\mathrm{G}, \mathrm{k}) \leq \mathrm{C}_{\mathrm{w}}^{*}(\mathrm{G}, \mathrm{k}+1)$ or $\mathrm{C}_{\mathrm{w}}^{*}\left(\mathrm{G}, \mathrm{k} \geq \mathrm{C}_{\mathrm{w}}^{*}(\mathrm{G}, \mathrm{k}+1)\right.$, respectively, for all $\mathrm{m}_{\mathrm{w}} \leq \mathrm{k} \leq \delta_{\mathrm{w}}^{*}(\mathrm{G})$.

For example, [2] : If $\mathrm{P}_{\mathrm{m}}^{2}$ is the square of a path $\mathrm{P}_{\mathrm{m}}$ of order $\mathrm{m} \geq 5$, then

$$
\mathrm{H}_{2}^{*}\left(\mathrm{P}_{\mathrm{m}}^{2} ; \mathrm{x}\right)=3(\mathrm{~m}-2) \mathrm{x}^{2}+\sum_{\mathrm{i}=3}^{\lceil\mathrm{m} / 2\rceil}[2 \mathrm{~m}-4 \mathrm{k}+3] \mathrm{x}^{\mathrm{k}} \text {, }
$$

is monotonically decreasing. 


\section{4. w-Hosoya Polynomial of Some Cog-Special Graphs:}

\subsection{Cog-complete Graph $\mathrm{K}_{\mathrm{m}}^{\mathrm{c}}$ :}

Definition: A cog-complete graph $\mathrm{K}_{\mathrm{m}}^{\mathrm{c}}$ is the graph constructed from a complete graph $\mathrm{K}_{\mathrm{m}}, \mathrm{m} \geq 3$, [3], of vertex set $\mathrm{V}=\left\{\mathrm{v}_{1}, \mathrm{v}_{2}, \ldots, \mathrm{v}_{\mathrm{m}}\right\}$ with $\mathrm{m}$ additional vertex set $\mathrm{U}=\left\{\mathrm{u}_{1}, \mathrm{u}_{2}, \ldots, \mathrm{u}_{\mathrm{m}}\right\}$, and $2 \mathrm{~m}$ edges $\left\{\mathrm{u}_{\mathrm{i}} \mathrm{v}_{\mathrm{i}}, \mathrm{u}_{\mathrm{i}} \mathrm{v}_{\mathrm{i}+1}: \mathrm{i}=1,2, \ldots, \mathrm{m}\right\},\left(\mathrm{v}_{\mathrm{m}+1} \equiv \mathrm{v}_{1}\right)$, as shown in Fig. 4.1.

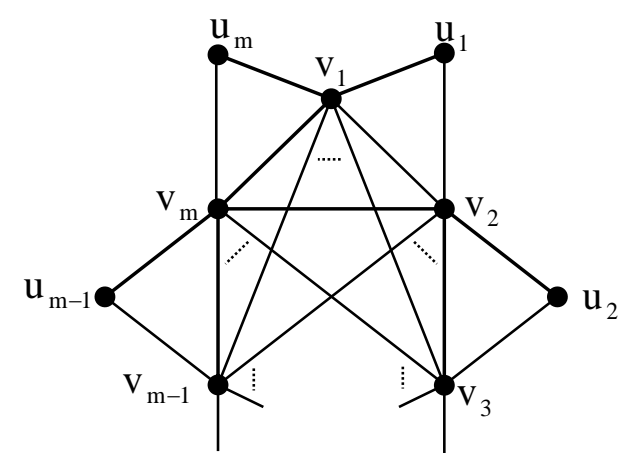

Fig. 4.1. $K_{m}^{c}$

It is clear that $\mathrm{p}\left(\mathrm{K}_{\mathrm{m}}^{*}\right)=2 \mathrm{~m}, \mathrm{q}\left(\mathrm{K}_{\mathrm{m}}^{*}\right)=\frac{1}{2} \mathrm{~m}(\mathrm{~m}+3)$, and $\mathrm{k}_{0}=2$. Thus, w must be 1 or 2 only.

Therefore, we take $\mathrm{w}=2$.

We notice that $\mathrm{m}_{2}\left(\mathrm{~K}_{\mathrm{m}}^{\mathrm{c}}\right)=2$, and $\delta_{2}^{*}\left(\mathrm{~K}_{\mathrm{m}}^{\mathrm{c}}\right)=3$.

Proposition 4.1.1: 2-Hosoya polynomial of $\mathrm{K}_{\mathrm{m}}^{\mathrm{c}}, \mathrm{m} \geq 4$ is

$$
\mathrm{H}_{2}^{*}\left(\mathrm{~K}_{\mathrm{m}}^{\mathrm{c}} ; \mathrm{x}\right)=(\mathrm{m}(3 \mathrm{~m}-1) / 2) \mathrm{x}^{2}+(\mathrm{m}(\mathrm{m}-1) / 2) \mathrm{x}^{3} \text {. }
$$

Proof:Let $u$ and $v$ be any two distinct vertices of , then we consider the following cases:

To find 2-Hosoya polynomial of $\mathrm{K}_{\mathrm{m}}^{\mathrm{c}}, \mathrm{m} \geq 4$, there are three cases:

Case (1): If $u, v \in U$, then

(i). If $\mathrm{u}$ and $\mathrm{v}$ are adjacent to a common vertex of $\mathrm{V}$, then there are two internally disjoint paths between the vertices $\mathrm{u}$ and $\mathrm{v}$ of lengths 2 and 3 ; therefore $\mathrm{d}_{2}^{*}(\mathrm{u}, \mathrm{v})=3$.Hence , the number of such pairs of vertices is $\mathrm{m}$.

(ii). If $\mathrm{u}$ and $\mathrm{v}$ are not adjacent to a common vertex of $\mathrm{V}$, then there are two internally disjoint paths between the vertices $u$ and $v$, each has length 3 , therefore $d_{2}^{*}(u, v)=3$. Hence, the number of such pairs of vertices is $\frac{1}{2} \mathrm{~m}(\mathrm{~m}-3)$.

(i) and (ii) produce the polynomial $\mathrm{H}_{2}^{*}\left(\tilde{\mathrm{U}}, \mathrm{K}_{\mathrm{m}}^{\mathrm{c}} ; \mathrm{x}\right)=\frac{1}{2} \mathrm{~m}(\mathrm{~m}-1) \mathrm{x}^{3}$.

Case (2): If $u, v \in V$, then there is always a container $\mathrm{C}(\mathrm{u}, \mathrm{v})$ of length 2. Thus, $\mathrm{H}_{2}^{*}\left(\tilde{\mathrm{V}}, \mathrm{K}_{\mathrm{m}}^{\mathrm{c}} ; \mathrm{x}\right)=\frac{1}{2} \mathrm{~m}(\mathrm{~m}-1) \mathrm{x}^{2}$.

Case (3): If $u \in U$, and $v \in V$, then 
(i). There are two internally disjoint paths between the vertices $\mathrm{u}$ and $\mathrm{v}$ of lengths 1 and 2, when $u v \in E\left(K_{m}^{c}\right)$, then $d_{2}^{*}(u, v)=2$. Hence, the number of such pairs of vertices is $2 \mathrm{~m}$.

(ii). There are two internally disjoint paths between the vertices $\mathrm{u}$ and $\mathrm{v}$ each of length 2 , when $u v \notin E\left(K_{m}^{c}\right)$, then $d_{2}^{*}(u, v)=2$. Hence, the number of such pairs of vertices is $\mathrm{m}(\mathrm{m}-2)$.

(i) and (ii) produce the polynomial $\mathrm{H}_{2}^{*}\left(\mathrm{M}, \mathrm{K}_{\mathrm{m}}^{\mathrm{c}} ; \mathrm{x}\right)=\mathrm{m}^{2} \mathrm{x}^{2}$, where $\mathrm{M}=\{(\mathrm{u}, \mathrm{v}): \mathrm{u} \in \mathrm{U}, \mathrm{v} \in \mathrm{V}\}$.

From three cases, we obtain

$$
\mathrm{H}_{2}^{*}\left(\mathrm{~K}_{\mathrm{m}}^{\mathrm{c}} ; \mathrm{x}\right)=(\mathrm{m}(3 \mathrm{~m}-1) / 2) \mathrm{x}^{2}+(\mathrm{m}(\mathrm{m}-1) / 2) \mathrm{x}^{3} \text {. }
$$

Corollary 4.1.2: For $\mathrm{m} \geq 4$,

$$
\mathrm{W}_{2}^{*}\left(\mathrm{~K}_{\mathrm{m}}^{\mathrm{c}}\right)=\mathrm{m}(9 \mathrm{~m}-5) / 2 \text {, and } \mu_{2}^{*}\left(\mathrm{~K}_{\mathrm{m}}^{\mathrm{c}}\right)=\frac{9 \mathrm{~m}-5}{4 \mathrm{~m}-2} ; \text { and } \mu_{2}^{*}\left(\mathrm{~K}_{\mathrm{m}}^{\mathrm{c}}\right) \leq 2.25 \text {. }
$$

\section{Remark:}

- $\mathrm{H}_{2}^{*}\left(\mathrm{~K}_{3}^{\mathrm{c}} ; \mathrm{x}\right)=12 \mathrm{x}^{2}+3 \mathrm{x}^{3}, \mathrm{~W}_{2}^{*}\left(\mathrm{~K}_{3}^{\mathrm{c}}\right)=33$, and $\mu_{2}^{*}\left(\mathrm{~K}_{3}^{\mathrm{c}}\right)=11 / 5$.

\subsection{Cog-star Graphs:}

Definition: [8] A cog-star graph $S_{m}^{c}$ is the graph constructed from a star $S_{m}, m \geq 4$, of vertex set $\mathrm{V}=\left\{\mathrm{v}_{1}, \mathrm{v}_{2}, \ldots, \mathrm{v}_{\mathrm{m}-1}, \mathrm{v}_{\mathrm{m}}\right\}$ with (m-1) additional vertex set $\mathrm{U}=\left\{\mathrm{u}_{1}, \mathrm{u}_{2}, \ldots, \mathrm{u}_{\mathrm{m}-2}, \mathrm{u}_{\mathrm{m}-1}\right\}$, and edges $\left\{\mathrm{u}_{\mathrm{i}} \mathrm{v}_{\mathrm{i}+1}, \mathrm{u}_{\mathrm{i}} \mathrm{v}_{\mathrm{i}+2}: \mathrm{i}=1,2, \ldots, \mathrm{m}-1\right\},\left(\mathrm{v}_{\mathrm{m}+1} \equiv \mathrm{v}_{2}\right)$ , as shown in Fig. 4.2.

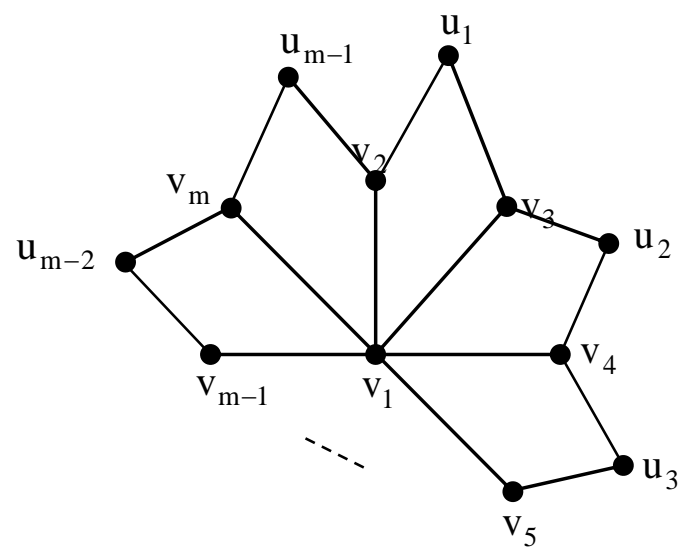

Fig. 4.2. $\mathrm{S}_{\mathrm{m}}^{\mathrm{c}}$

It is clear that $\mathrm{p}\left(\mathrm{S}_{\mathrm{m}}^{*}\right)=2 \mathrm{~m}-1, \mathrm{q}\left(\mathrm{S}_{\mathrm{m}}^{*}\right)=3(\mathrm{~m}-1)$, we notice that $\mathrm{w}=2$, $\delta_{2}^{*}\left(S_{m}^{c}\right)=m-1$, and $m_{2}\left(S_{m}^{c}\right)=2, m \geq 5$.

Theorem 4.2.1: For $\mathrm{m} \geq 6$,

$$
\mathrm{H}_{2}^{*}\left(\mathrm{~S}_{\mathrm{m}}^{\mathrm{c}} ; \mathrm{x}\right)=(\mathrm{m}-1)\left[3 \mathrm{x}^{3}+\mathrm{x}^{4}+\mathrm{x}^{\mathrm{m}-1}+2 \sum_{\mathrm{i}=2}^{\mathrm{m}-2} \mathrm{x}^{\mathrm{i}}\right] .
$$

Proof: When $w=2$, there are four cases: 
Case (1): If $u, u^{\prime} \in U, u \neq u^{\prime}$, then there are two internally disjoint paths between $u$ and $\mathrm{u}^{\prime}$ having lengths 2 and 4 when $\mathrm{u}$ and $\mathrm{u}^{\prime}$ are adjacent to a common vertex of $\mathrm{V}$, then $\mathrm{d}_{2}^{*}\left(\mathrm{u}, \mathrm{u}^{\prime} \mid \mathrm{S}_{\mathrm{m}}^{\mathrm{c}}\right)=4$.

The number of such pairs of vertices $\left\{u, u^{\prime}\right\}$ such that $d_{2}^{*}\left(u, u^{\prime} \mid S_{m}^{c}\right)=4$ is $(m-1)$.

Also, there are two internally disjoint paths between $u$ and $\mathrm{u}^{\prime}$ having length 4 and $\mathrm{d}\left(\mathrm{u}, \mathrm{u}^{\prime} \mid \mathrm{S}_{\mathrm{m}}^{\mathrm{c}}-\left\{\mathrm{v}_{1}\right\}\right)$ when $\mathrm{u}$ and $\mathrm{u}^{\prime}$ are not adjacent to a common vertex of $\mathrm{V}$.

It is clear that then $\mathrm{d}\left(\mathrm{u}, \mathrm{u}^{\prime} \mid \mathrm{S}_{\mathrm{m}}^{\mathrm{c}}-\left\{\mathrm{v}_{1}\right\}\right)=4,6,8, \ldots, 2\left\lfloor\frac{\mathrm{m}-1}{2}\right\rfloor$, then

$\mathrm{d}_{2}^{*}\left(\mathrm{u}, \mathrm{u}^{\prime} \mid \mathrm{S}_{\mathrm{m}}^{\mathrm{c}}\right)=\mathrm{d}\left(\mathrm{u}, \mathrm{u}^{\prime} \mid \mathrm{S}_{\mathrm{m}}^{\mathrm{c}}-\left\{\mathrm{v}_{1}\right\}\right)$.

Let $\mathrm{d}\left(\mathrm{u}, \mathrm{u}^{\prime} \mid \mathrm{S}_{\mathrm{m}}^{\mathrm{c}}-\left\{\mathrm{v}_{1}\right\}\right)=\mathrm{k}$, for $\mathrm{k}=4,6,8, \ldots, 2\left\lfloor\frac{\mathrm{m}-1}{2}\right\rfloor$.

Hence, the number of pairs $\left\{\mathrm{u}, \mathrm{u}^{\prime}\right\}$ when $\mathrm{u}$ and $\mathrm{u}^{\prime}$ are not adjacent to a common vertex of $\mathrm{V}$ such that $\mathrm{d}_{2}^{*}\left(\mathrm{u}, \mathrm{u}^{\prime} \mid \mathrm{S}_{\mathrm{m}}^{\mathrm{c}}\right)=\mathrm{k}$, for $\mathrm{k}=4,6,8, \ldots, 2\left\lfloor\frac{\mathrm{m}-1}{2}\right\rfloor$ is $\mathrm{m}-1$, except when $\mathrm{m}$ is odd, and $\mathrm{d}_{2}^{*}\left(\mathrm{u}, \mathrm{u}^{\prime} \mid \mathrm{S}_{\mathrm{m}}^{\mathrm{c}}\right)=\mathrm{m}-1$, then the number of such pairs $\left\{\mathrm{u}, \mathrm{u}^{\prime}\right\}$ is $\frac{\mathrm{m}-1}{2}$.

Thus, from this case, we get

$$
\mathrm{H}_{2}^{*}\left(\tilde{\mathrm{U}}, \mathrm{S}_{\mathrm{m}}^{\mathrm{c}} ; \mathrm{x}\right)=(\mathrm{m}-1)\left[\begin{array}{l}
\mathrm{x}^{4}+\sum_{\mathrm{i}=2}^{\frac{\mathrm{m}-3}{2}} \mathrm{x}^{2 \mathrm{i}}+\frac{1}{2} \mathrm{x}^{\mathrm{m}-1}, \text { if } \mathrm{m} \text { is odd }, \\
\mathrm{x}^{4}+\sum_{\mathrm{i}=2}^{\frac{\mathrm{m}}{2}-1} \mathrm{x}^{2 \mathrm{i}}, \text { if } \mathrm{m} \text { is even. }
\end{array}\right.
$$

Case (2): If $\mathrm{v}, \mathrm{v}^{\prime} \in \mathrm{R}=\mathrm{V}-\left\{\mathrm{v}_{1}\right\}, \mathrm{v} \neq \mathrm{v}^{\prime}$, then there are three internally disjoint paths between $v$ and $v^{\prime}$ having lengths $2, d\left(v, v^{\prime} \mid S_{m}^{c}-\left\{v_{1}\right\}\right)$ and $2(m-1)-d\left(v, v^{\prime} \mid S_{m}^{c}-\left\{v_{1}\right\}\right)$. Thus,

$$
\begin{aligned}
& \mathrm{d}_{2}^{*}\left(\mathrm{v}, \mathrm{v}^{\prime} \mid \mathrm{S}_{\mathrm{m}}^{\mathrm{c}}\right)=\min \left[\max \left\{2, \mathrm{~d}\left(\mathrm{v}, \mathrm{v}^{\prime} \mid \mathrm{S}_{\mathrm{m}}^{\mathrm{c}}-\left\{\mathrm{v}_{1}\right\}\right)\right\}, \max \left\{2,2(\mathrm{~m}-1)-\mathrm{d}\left(\mathrm{v}, \mathrm{v}^{\prime} \mid \mathrm{S}_{\mathrm{m}}^{\mathrm{c}}-\left\{\mathrm{v}_{1}\right\}\right)\right\},\right. \\
&\left.\left.\max \left\{\mathrm{d}\left(\mathrm{v}, \mathrm{v}^{\prime} \mid \mathrm{S}_{\mathrm{m}}^{\mathrm{c}}-\left\{\mathrm{v}_{1}\right\}\right)\right\}, 2(\mathrm{~m}-1)-\mathrm{d}\left(\mathrm{v}, \mathrm{v}^{\prime} \mid \mathrm{S}_{\mathrm{m}}^{\mathrm{c}}-\left\{\mathrm{v}_{1}\right\}\right)\right\}\right] .
\end{aligned}
$$

Since $d\left(v, v^{\prime} \mid S_{m}^{c}-\left\{v_{1}\right\}\right)=2,4,6, \ldots, 2\left\lfloor\frac{m-1}{2}\right\rfloor$, then $d_{2}^{*}\left(v, v^{\prime} \mid S_{m}^{c}\right)=d\left(v, v^{\prime} \mid S_{m}^{c}-\left\{v_{1}\right\}\right)$.

Let $\mathrm{d}\left(\mathrm{v}, \mathrm{v}^{\prime} \mid \mathrm{S}_{\mathrm{m}}^{\mathrm{c}}-\left\{\mathrm{v}_{1}\right\}\right)=\mathrm{k}$, for $\mathrm{k}=2,4,6, \ldots, 2\left\lfloor\frac{\mathrm{m}-1}{2}\right\rfloor$.

Hence, the number of pairs $\left\{\mathrm{v}, \mathrm{v}^{\prime}\right\}$ such that $\mathrm{d}_{2}^{*}\left(\mathrm{v}, \mathrm{v}^{\prime} \mid \mathrm{S}_{\mathrm{m}}^{\mathrm{c}}\right)=\mathrm{k}$, for $\mathrm{k}=2,4,6, \ldots, 2\left\lfloor\frac{\mathrm{m}-1}{2}\right\rfloor$ is $\mathrm{m}-1$, except when $\mathrm{m}$ is odd, and $\mathrm{d}_{2}^{*}\left(\mathrm{v}, \mathrm{v}^{\prime} \mid \mathrm{S}_{\mathrm{m}}^{\mathrm{c}}\right)=\mathrm{m}-1$, then the number of such pairs $\left\{v, v^{\prime}\right\}$ is $\frac{m-1}{2}$.

Thus, from this case, we get 


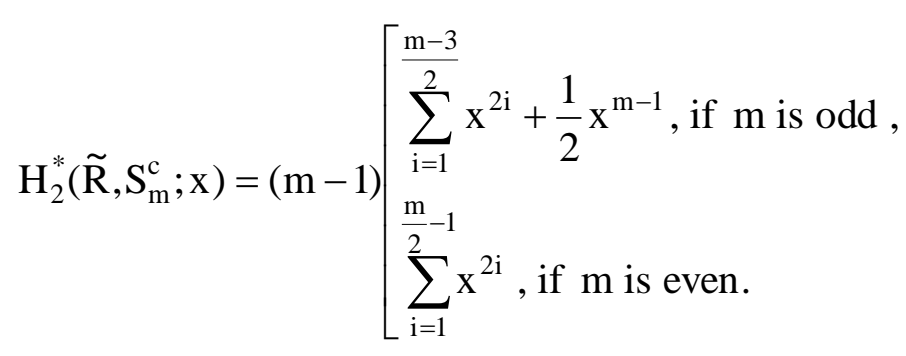

Case (3): If $\mathrm{u} \in \mathrm{U}$, and $\mathrm{v} \in \mathrm{V}-\left\{\mathrm{v}_{1}\right\}$, then

either there are two internally disjoint paths between the vertices $\mathrm{u}$ and $\mathrm{v}$ of length 1 and 3 when $u v \in E\left(S_{m}^{c}\right)$, then $d_{2}^{*}\left(u, v \mid S_{m}^{c}\right)=3$.

It is clear that the number of pairs of vertices $\{\mathrm{u}, \mathrm{v}\}$ with $\mathrm{uv} \in \mathrm{E}\left(\mathrm{S}_{\mathrm{m}}^{\mathrm{c}}\right)$ is $2(\mathrm{~m}-1)$.

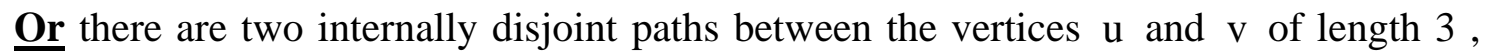
and $\mathrm{d}\left(\mathrm{u}, \mathrm{v} \mid \mathrm{S}_{\mathrm{m}}^{\mathrm{c}}-\left\{\mathrm{v}_{1}\right\}\right)$ when $\mathrm{uv} \notin \mathrm{E}\left(\mathrm{S}_{\mathrm{m}}^{\mathrm{c}}\right)$.

It is clear that $\mathrm{d}\left(\mathrm{u}, \mathrm{v} \mid \mathrm{S}_{\mathrm{m}}^{\mathrm{c}}-\left\{\mathrm{v}_{1}\right\}\right)=3,5,7, \ldots, 2\left\lfloor\frac{\mathrm{m}}{2}\right\rfloor-1, \quad$ then $\mathrm{d}_{2}^{*}\left(\mathrm{u}, \mathrm{v} \mid \mathrm{S}_{\mathrm{m}}^{\mathrm{c}}\right)=\mathrm{d}\left(\mathrm{u}, \mathrm{v} \mid \mathrm{S}_{\mathrm{m}}^{\mathrm{c}}-\left\{\mathrm{v}_{1}\right\}\right)$

Let $\mathrm{d}\left(\mathrm{u}, \mathrm{v} \mid \mathrm{S}_{\mathrm{m}}^{\mathrm{c}}-\left\{\mathrm{v}_{1}\right\}\right)=\mathrm{k}$, for $\mathrm{k}=3,5,7, \ldots, 2\left\lfloor\frac{\mathrm{m}}{2}\right\rfloor-1$.

Hence, the number of pairs of $\{u, v\}, \quad u v \notin E\left(S_{m}^{c}\right)$, such that $d_{2}^{*}\left(u, v \mid S_{m}^{c}\right)=k$, for $\mathrm{k}=3,5,7, \ldots, 2\left\lfloor\frac{\mathrm{m}}{2}\right\rfloor-1$, is $2(\mathrm{~m}-1)$, except when $\mathrm{m}$ is even and $\mathrm{d}_{2}^{*}\left(\mathrm{u}, \mathrm{v} \mid \mathrm{S}_{\mathrm{m}}^{\mathrm{c}}\right)=\mathrm{m}-1$, then the number of pairs $\{\mathrm{u}, \mathrm{v}\}$ is $(\mathrm{m}-1)$.

Thus, in this case, we get

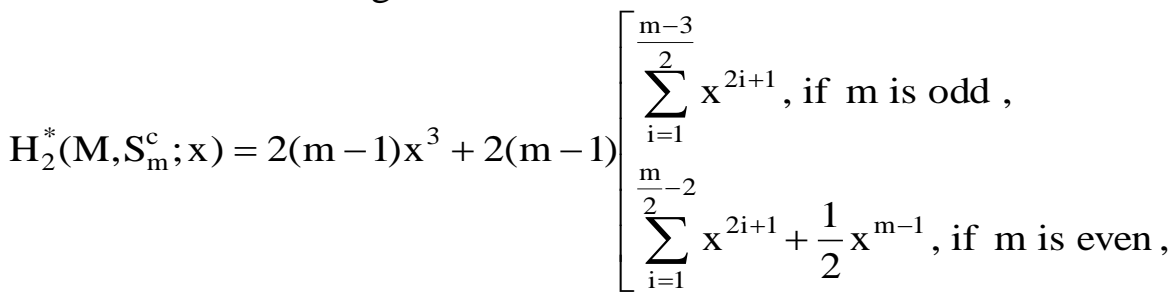

where $\mathrm{M}=\left\{(\mathrm{u}, \mathrm{v}): \mathrm{u} \in \mathrm{U}, \mathrm{v} \in \mathrm{V}-\left\{\mathrm{v}_{1}\right\}\right\}$.

Case (4): There are two internally disjoint paths between $v_{1}$ and $u_{i}, 1 \leq i \leq m-1$, that have length 2 , then $\mathrm{d}_{2}^{*}\left(\mathrm{v}_{1}, \mathrm{u}_{\mathrm{i}} \mid \mathrm{S}_{\mathrm{m}}^{\mathrm{c}}\right)=2,1 \leq \mathrm{i} \leq \mathrm{m}-1$, and there are three internally disjoint paths between $\mathrm{v}_{1}$ and $\mathrm{v}_{\mathrm{i}}, 2 \leq \mathrm{i} \leq \mathrm{m}$, that have length 1,3 , and 3 , then $\left.\left.\mathrm{d}_{2}^{*}\left(\mathrm{v}_{1}, \mathrm{v}_{\mathrm{i}} \mid \mathrm{S}_{\mathrm{m}}^{\mathrm{c}}\right)=\min [\max \{1,3\}, \max \{1,3)\}, \max \{3,3)\right\}\right]=3,2 \leq \mathrm{i} \leq \mathrm{m}$.

Hence, $\mathrm{H}_{2}^{*}\left(\mathrm{v}_{1}, \mathrm{~S}_{\mathrm{m}}^{\mathrm{c}} ; \mathrm{x}\right)=(\mathrm{m}-1) \mathrm{x}^{2}+(\mathrm{m}-1) \mathrm{x}^{3}$

From $\mathrm{H}_{2}^{*}\left(\mathrm{~S}_{\mathrm{m}}^{\mathrm{c}} ; \mathrm{x}\right)=\mathrm{H}_{2}^{*}\left(\tilde{\mathrm{U}}, \mathrm{S}_{\mathrm{m}}^{\mathrm{c}} ; \mathrm{x}\right)+\mathrm{H}_{2}^{*}\left(\tilde{\mathrm{R}}, \mathrm{S}_{\mathrm{m}}^{\mathrm{c}} ; \mathrm{x}\right)+\mathrm{H}_{2}^{*}\left(\mathrm{M}, \mathrm{S}_{\mathrm{m}}^{\mathrm{c}} ; \mathrm{x}\right)+\mathrm{H}_{2}^{*}\left(\mathrm{v}_{1}, \mathrm{~S}_{\mathrm{m}}^{\mathrm{c}} ; \mathrm{x}\right)$, we get (4.2.1).

We notice from (4.2.1), that the 2-Hosoya polynomial of $\mathrm{S}_{\mathrm{m}}^{\mathrm{c}}, \mathrm{m} \geq 9$, is 3-semipalindromic.

\section{Remark:}


- $\mathrm{H}_{2}^{*}\left(\mathrm{~S}_{4}^{\mathrm{c}} ; \mathrm{x}\right)=6 \mathrm{x}^{2}+12 \mathrm{x}^{3}+3 \mathrm{x}^{4}$.

- $\mathrm{H}_{2}^{*}\left(\mathrm{~S}_{5}^{\mathrm{c}} ; \mathrm{x}\right)=8 \mathrm{x}^{2}+20 \mathrm{x}^{3}+8 \mathrm{x}^{4}$.

Corollary 4.2.2: For $\mathrm{m} \geq 4$,

(a) $\mathrm{W}_{2}^{*}\left(\mathrm{~S}_{\mathrm{m}}^{\mathrm{c}}\right)=(\mathrm{m}-1)\left(\mathrm{m}^{2}-2 \mathrm{~m}+12\right)$.

(b) $\mu_{2}^{*}\left(S_{m}^{c}\right)=\left(m^{2}-2 m+12\right) /(2 m-1)$.

(c) $\mu_{2}^{*}\left(S_{m}^{c}\right) \leq \frac{m+1}{2}$, for all $\mathrm{m} \geq 5$.

\subsection{Cog-wheel Graphs:}

Definition: [8] A cog-wheel graph $\mathrm{W}_{\mathrm{m}}^{\mathrm{c}}$ is the graph constructed from a wheel $\mathrm{W}_{\mathrm{m}}, \mathrm{m} \geq 4$, of order $\mathrm{m}$, with vertex set $\mathrm{V}=\left\{\mathrm{v}_{1}, \mathrm{v}_{2}, \ldots, \mathrm{v}_{\mathrm{m}-1}, \mathrm{v}_{\mathrm{m}}\right\}$, and with (m-1) additional vertex set $\mathrm{U}=\left\{\mathrm{u}_{1}, \mathrm{u}_{2}, \ldots, \mathrm{u}_{\mathrm{m}-2}, \mathrm{u}_{\mathrm{m}-1}\right\}, \quad$ and edges $\left\{\mathrm{u}_{\mathrm{i}} \mathrm{v}_{\mathrm{i}+1}, \mathrm{u}_{\mathrm{i}} \mathrm{v}_{\mathrm{i}+2}: \mathrm{i}=1,2, \ldots, \mathrm{m}-1\right\},\left(\mathrm{v}_{\mathrm{m}+1} \equiv \mathrm{v}_{2}\right)$, as shown in Fig. 4.3.

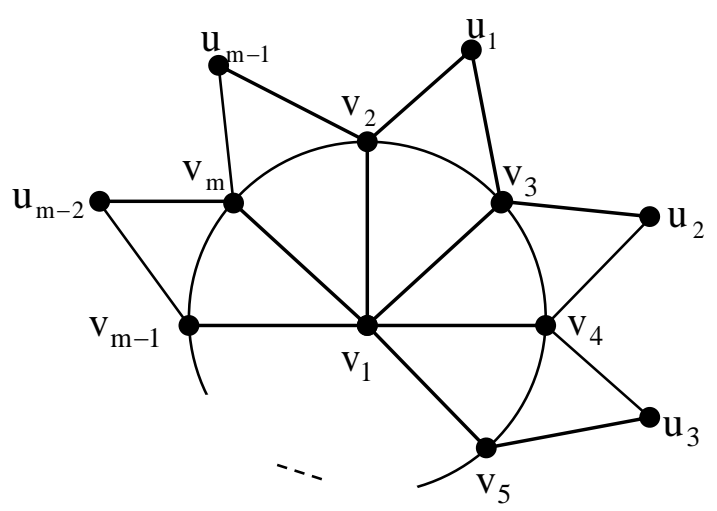

Fig. 4.3 $\mathrm{W}_{\mathrm{m}}^{\mathrm{c}}$

It is clear that $\mathrm{p}\left(\mathrm{W}_{\mathrm{m}}^{*}\right)=2 \mathrm{~m}-1, \mathrm{q}\left(\mathrm{W}_{\mathrm{m}}^{*}\right)=4(\mathrm{~m}-1)$, and $\mathrm{w}=2$.

$\delta_{2}^{*}\left(\mathrm{~W}_{\mathrm{m}}^{\mathrm{c}}\right)=\left\lfloor\frac{\mathrm{m}+1}{2}\right\rfloor, \mathrm{m} \geq 7$, and $\mathrm{m}_{\mathrm{w}}\left(\mathrm{S}_{\mathrm{m}}^{\mathrm{c}}\right)=2, \mathrm{~m} \geq 4$.

Theorem 4.3.1: For $\mathrm{m} \geq 8$, then

$$
\begin{aligned}
\mathrm{H}_{2}^{*}\left(\mathrm{~W}_{\mathrm{m}}^{\mathrm{c}} ; \mathrm{x}\right) & =2(\mathrm{~m}-1) \mathrm{x}^{2}+(\mathrm{m}-1) \mathrm{x}^{3}+2(\mathrm{~m}-1) \mathrm{x}^{4} \\
& +4(\mathrm{~m}-1)\left[\begin{array}{l}
\sum_{\mathrm{i}=2}^{\frac{\mathrm{m}-3}{2}} \mathrm{x}^{\mathrm{i}}+\frac{7}{8} \mathrm{x}^{\frac{\mathrm{m}-1}{2}}+\frac{1}{8} \mathrm{x}^{\frac{\mathrm{m}+1}{2}}, \text { if } \mathrm{m} \text { is odd }, \\
\sum_{\mathrm{i}=2}^{\frac{\mathrm{m}}{2}-1} \mathrm{x}^{\mathrm{i}}+\frac{1}{2} \mathrm{x}^{\frac{\mathrm{m}}{2}}, \text { if } \mathrm{m} \text { is even },
\end{array}\right.
\end{aligned}
$$

Proof: To prove (4.3.1), we consider three cases

Case (1): There are two internally disjoint paths between $\mathrm{u}_{\mathrm{i}}$ and $\mathrm{u}_{\mathrm{i}+1}, 1 \leq \mathrm{i} \leq \mathrm{m}-1$, $\left(\mathrm{u}_{\mathrm{m}} \equiv \mathrm{u}_{1}\right)$ having length 2 and 4 , then $\mathrm{d}_{2}^{*}\left(\mathrm{u}_{\mathrm{i}}, \mathrm{u}_{\mathrm{i}+1} \mid \mathrm{W}_{\mathrm{m}}^{\mathrm{c}}\right)=4,1 \leq \mathrm{i} \leq \mathrm{m}-1,\left(\mathrm{u}_{\mathrm{m}} \equiv \mathrm{u}_{1}\right)$, and 
the number of pairs of vertices $\left\{\mathrm{u}_{\mathrm{i}}, \mathrm{u}_{\mathrm{i}+1}\right\}, 1 \leq \mathrm{i} \leq \mathrm{m}-1,\left(\mathrm{u}_{\mathrm{m}} \equiv \mathrm{u}_{1}\right)$ is $(\mathrm{m}-1)$. In addition , there are two internally disjoint paths between $u_{i}$ and $u_{i+2}, \quad 1 \leq i \leq m-1$, $\left(\mathrm{u}_{\mathrm{m}} \equiv \mathrm{u}_{1}\right.$ and $\mathrm{u}_{\mathrm{m}+1} \equiv \mathrm{u}_{2}$ ) having length 3 and 4 , then $\mathrm{d}_{2}^{*}\left(\mathrm{u}_{\mathrm{i}}, \mathrm{u}_{\mathrm{i}+2} \mid \mathrm{W}_{\mathrm{m}}^{\mathrm{c}}\right)=4,1 \leq \mathrm{i} \leq \mathrm{m}-1$, $\left(\mathrm{u}_{\mathrm{m}} \equiv \mathrm{u}_{1}\right.$ and $\left.\mathrm{u}_{\mathrm{m}+1} \equiv \mathrm{u}_{2}\right)$, and the number of pairs of vertices $\left\{\mathrm{u}_{\mathrm{i}}, \mathrm{u}_{\mathrm{i}+2}\right\}, 1 \leq \mathrm{i} \leq \mathrm{m}-1$, $\left(\mathrm{u}_{\mathrm{m}} \equiv \mathrm{u}_{1}\right.$ and $\left.\mathrm{u}_{\mathrm{m}+1} \equiv \mathrm{u}_{2}\right)$ is $(\mathrm{m}-1)$.

Now, there are two internally disjoint paths between the vertices $u_{i}$ and $u_{j}$, $1 \leq \mathrm{i} \leq \mathrm{m}-4, \mathrm{i}+3 \leq \mathrm{j} \leq \mathrm{m}-1$, (except for $\mathrm{i}=1, \mathrm{j} \neq \mathrm{m}-2, \mathrm{~m}-1$; and for $\mathrm{i}=2, \mathrm{j} \neq \mathrm{m}-1$ ) having lengths 4 , and $d\left(u_{i}, u_{j} \mid W_{m}^{c}-\left\{v_{1}\right\}\right)$. Since, $4 \leq d\left(u_{i}, u_{j} \mid W_{m}^{c}-\left\{v_{1}\right\}\right) \leq\left\lfloor\frac{m+1}{2}\right\rfloor$, then $\mathrm{d}_{2}^{*}\left(\mathrm{u}_{\mathrm{i}}, \mathrm{u}_{\mathrm{j}} \mid \mathrm{W}_{\mathrm{m}}^{\mathrm{c}}\right)=\mathrm{d}\left(\mathrm{u}_{\mathrm{i}}, \mathrm{u}_{\mathrm{j}} \mid \mathrm{W}_{\mathrm{m}}^{\mathrm{c}}-\left\{\mathrm{v}_{1}\right\}\right)$.

Let $\mathrm{d}\left(\mathrm{u}_{\mathrm{i}}, \mathrm{u}_{\mathrm{j}} \mid \mathrm{W}_{\mathrm{m}}^{\mathrm{c}}-\left\{\mathrm{v}_{1}\right\}\right)=\mathrm{k}$, for all $4 \leq \mathrm{k} \leq\left\lfloor\frac{\mathrm{m}+1}{2}\right\rfloor$.

The number of pairs $\left\{\mathrm{u}_{\mathrm{i}}, \mathrm{u}_{\mathrm{j}}\right\}$ such that $\mathrm{d}_{2}^{*}\left(\mathrm{u}_{\mathrm{i}}, \mathrm{u}_{\mathrm{j}} \mid \mathrm{W}_{\mathrm{m}}^{\mathrm{c}}\right)=\mathrm{k}$, for all $4 \leq \mathrm{k} \leq\left\lfloor\frac{\mathrm{m}+1}{2}\right\rfloor$, is $\mathrm{m}-1$, except if $\mathrm{m}$ is odd, then the number of $\left\{\mathrm{u}_{\mathrm{i}}, \mathrm{u}_{\mathrm{j}}\right\}$ such that $\mathrm{d}_{2}^{*}\left(\mathrm{u}_{\mathrm{i}}, \mathrm{u}_{\mathrm{j}} \mid \mathrm{W}_{\mathrm{m}}^{\mathrm{c}}\right)=\frac{\mathrm{m}+1}{2}$, is $\frac{m-1}{2}, 1 \leq \mathrm{i} \leq \mathrm{m}-4, \mathrm{i}+3 \leq \mathrm{j} \leq \mathrm{m}-1$, (except for $\mathrm{i}=1, \mathrm{j} \neq \mathrm{m}-2, \mathrm{~m}-1$; and for $\mathrm{i}=2, \mathrm{j} \neq \mathrm{m}-1)$.

Hence,

$$
\mathrm{H}_{2}^{*}\left(\tilde{\mathrm{U}}, \mathrm{W}_{\mathrm{m}}^{\mathrm{c}} ; \mathrm{x}\right)=2(\mathrm{~m}-1) \mathrm{x}^{4}+(\mathrm{m}-1)\left[\begin{array}{l}
\sum_{\mathrm{i}=4}^{\frac{\mathrm{m}-1}{2}} \mathrm{x}^{\mathrm{i}}+\frac{1}{2} \mathrm{x}^{\frac{\mathrm{m}+1}{2}}, \text { if } \mathrm{m} \text { is odd }, \\
\sum_{\mathrm{i}=4}^{\frac{\mathrm{m}}{2}} \mathrm{x}^{\mathrm{i}}, \text { if } \mathrm{m} \text { is even. }
\end{array}\right.
$$

Case (2): If $v, v^{\prime} \in V, v \neq v^{\prime}$, then we consider 3 subcases:

(I) If $\mathrm{v}, \mathrm{v}^{\prime} \in \mathrm{V}-\left\{\mathrm{v}_{1}\right\}$, and $\mathrm{vv}^{\prime} \in \mathrm{E}\left(\mathrm{W}_{\mathrm{m}}^{\mathrm{c}}\right)$, then there are four internally disjoint paths between $v$ and $v^{\prime}$ having lengths $1,2,2, m-2$, then $d_{2}^{*}\left(v, v^{\prime} \mid W_{m}^{c}\right)=\min \{2, m-2\}=2$, $\mathrm{m} \geq 4$.

Hence, the number of pairs $\left\{v, v^{\prime}\right\}$, such that $d_{2}^{*}\left(v, v^{\prime} \mid W_{m}^{c}\right)=2, v^{\prime} \in E\left(W_{m}^{c}\right)$ is $(m-1)$.

(II) If $\mathrm{v}=\mathrm{v}_{1}, \mathrm{v}^{\prime}=\mathrm{v}_{\mathrm{i}}, 2 \leq \mathrm{i} \leq \mathrm{m}$, then there are three internally disjoint paths between the vertices $\mathrm{v}_{1}$ and $\mathrm{v}_{\mathrm{i}}, 2 \leq \mathrm{i} \leq \mathrm{m}$ having lengths 1,2 , and 2 , then $\mathrm{d}_{2}^{*}\left(\mathrm{v}_{1}, \mathrm{v}_{\mathrm{i}} \mid \mathrm{W}_{\mathrm{m}}^{\mathrm{c}}\right)=2$, $2 \leq \mathrm{i} \leq \mathrm{m}$.

It is clear that the number of such pairs $\left\{\mathrm{v}_{1}, \mathrm{v}_{\mathrm{i}}\right\}, 2 \leq \mathrm{i} \leq \mathrm{m}$, is (m-1).

(III) If $\mathrm{v}, \mathrm{v}^{\prime} \in \mathrm{V}-\left\{\mathrm{v}_{1}\right\}$, and $\mathrm{vv}^{\prime} \notin \mathrm{E}\left(\mathrm{W}_{\mathrm{m}}^{\mathrm{c}}\right)$, then there are three internally disjoint paths between the vertices $\mathrm{v}$ and $\mathrm{v}^{\prime}$, having lengths $2, \mathrm{~d}\left(\mathrm{v}, \mathrm{v}^{\prime} \mid \mathrm{W}_{\mathrm{m}}^{\mathrm{c}}-\left\{\mathrm{v}_{1}\right\}\right)$ and $(\mathrm{m}-1)-\mathrm{d}\left(\mathrm{v}, \mathrm{v}^{\prime} \mid \mathrm{W}_{\mathrm{m}}^{\mathrm{c}}-\left\{\mathrm{v}_{1}\right\}\right)$. Then 


$$
\begin{gathered}
\mathrm{d}_{2}^{*}\left(\mathrm{v}, \mathrm{v}^{\prime} \mid \mathrm{W}_{\mathrm{m}}^{\mathrm{c}}\right)=\min \left\{\max \left\{2, \mathrm{~d}\left(\mathrm{v}, \mathrm{v}^{\prime} \mid \mathrm{W}_{\mathrm{m}}^{\mathrm{c}}-\left\{\mathrm{v}_{1}\right\}\right)\right\}, \max \left\{2,(\mathrm{~m}-1)-\mathrm{d}\left(\mathrm{v}, \mathrm{v}^{\prime} \mid \mathrm{W}_{\mathrm{m}}^{\mathrm{c}}-\left\{\mathrm{v}_{1}\right\}\right)\right.\right. \\
, \max \left\{\mathrm{d}\left(\mathrm{v}, \mathrm{v}^{\prime} \mid \mathrm{W}_{\mathrm{m}}^{\mathrm{c}}-\left\{\mathrm{v}_{1}\right\}\right),(\mathrm{m}-1)-\mathrm{d}\left(\mathrm{v}, \mathrm{v}^{\prime} \mid \mathrm{W}_{\mathrm{m}}^{\mathrm{c}}-\left\{\mathrm{v}_{1}\right\}\right)\right\} .
\end{gathered}
$$

Since $2 \leq \mathrm{d}\left(\mathrm{v}, \mathrm{v}^{\prime} \mid \mathrm{W}_{\mathrm{m}}^{\mathrm{c}}-\left\{\mathrm{v}_{1}\right\}\right) \leq\left\lfloor\frac{\mathrm{m}-1}{2}\right\rfloor$, then,

$$
\mathrm{d}_{2}^{*}\left(\mathrm{v}, \mathrm{v}^{\prime} \mid \mathrm{W}_{\mathrm{m}}^{\mathrm{c}}\right)=\min \left\{\mathrm{d}\left(\mathrm{v}, \mathrm{v}^{\prime} \mid \mathrm{W}_{\mathrm{m}}^{\mathrm{c}}-\left\{\mathrm{v}_{1}\right\}\right),(\mathrm{m}-1)-\mathrm{d}\left(\mathrm{v}, \mathrm{v}^{\prime} \mid \mathrm{W}_{\mathrm{m}}^{\mathrm{c}}-\left\{\mathrm{v}_{1}\right\}\right)=\mathrm{d}\left(\mathrm{v}, \mathrm{v}^{\prime} \mid \mathrm{W}_{\mathrm{m}}^{\mathrm{c}}-\left\{\mathrm{v}_{1}\right\}\right)\right. \text {. }
$$

Let $\mathrm{d}\left(\mathrm{v}, \mathrm{v}^{\prime} \mid \mathrm{W}_{\mathrm{m}}^{\mathrm{c}}-\left\{\mathrm{v}_{1}\right\}\right)=\mathrm{k}$, for all $2 \leq \mathrm{k} \leq\left\lfloor\frac{\mathrm{m}-1}{2}\right\rfloor$, then the number of pairs $\left\{\mathrm{v}, \mathrm{v}^{\prime}\right\}$, $\mathrm{vv}^{\prime} \notin \mathrm{E}\left(\mathrm{W}_{\mathrm{m}}^{\mathrm{c}}\right)$ such that $\mathrm{d}_{2}^{*}\left(\mathrm{v}, \mathrm{v}^{\prime} \mid \mathrm{W}_{\mathrm{m}}^{\mathrm{c}}\right)=\mathrm{k}$, for all $2 \leq \mathrm{k} \leq\left\lfloor\frac{\mathrm{m}-1}{2}\right\rfloor$, is $(\mathrm{m}-1)$, except when $\mathrm{m}$ is odd and $\mathrm{d}_{2}^{*}\left(\mathrm{v}, \mathrm{v}^{\prime} \mid \mathrm{W}_{\mathrm{m}}^{\mathrm{c}}\right)=\frac{\mathrm{m}-1}{2}$, then the number of pairs $\left\{\mathrm{v}, \mathrm{v}^{\prime}\right\}$ is $\frac{\mathrm{m}-1}{2}$.

Hence,

$$
\mathrm{H}_{2}^{*}\left(\tilde{\mathrm{V}}, \mathrm{W}_{\mathrm{m}}^{\mathrm{c}} ; \mathrm{x}\right)=2(\mathrm{~m}-1) \mathrm{x}^{2}+(\mathrm{m}-1)\left[\begin{array}{l}
\sum_{\mathrm{i}=2}^{\frac{\mathrm{m}-3}{2}} \mathrm{x}^{\mathrm{i}}+\frac{1}{2} \mathrm{x}^{\frac{\mathrm{m}-1}{2}}, \text { if } \mathrm{m} \text { is odd }, \\
\frac{\mathrm{m}}{2}-1 \\
\sum_{\mathrm{i}=2} \mathrm{x}^{\mathrm{i}}, \text { if } \mathrm{m} \text { is even. }
\end{array}\right.
$$

Case (3): If $u \in U$ and $v \in V$, then there are two internally disjoint paths between the vertices $u$ and $v$ for each of the following subcases :

(a) If $\mathrm{u}=\mathrm{u}_{\mathrm{i}}, 1 \leq \mathrm{i} \leq \mathrm{m}-1$, and $\mathrm{v}=\mathrm{v}_{1}$, then two paths each has length 2; therefore $\mathrm{d}_{2}^{*}\left(\mathrm{v}_{1}, \mathrm{u}_{\mathrm{i}} \mid \mathrm{W}_{\mathrm{m}}^{\mathrm{c}}\right)=2,1 \leq \mathrm{i} \leq \mathrm{m}-1$, and the number of these pairs is $\mathrm{m}-1$.

(b) If $\mathrm{v} \in \mathrm{V}-\left\{\mathrm{v}_{1}\right\}$ and $\mathrm{uv} \in \mathrm{E}\left(\mathrm{W}_{\mathrm{m}}^{\mathrm{c}}\right)$, then the two paths have length 1 , and 2, therefore $\mathrm{d}_{2}^{*}\left(\mathrm{v}, \mathrm{u} \mid \mathrm{W}_{\mathrm{m}}^{\mathrm{c}}\right)=2$, and the number of such pairs $\{\mathrm{u}, \mathrm{v}\}$ is $2(\mathrm{~m}-1)$.

(c) If $\mathrm{v} \in \mathrm{V}-\left\{\mathrm{v}_{1}\right\}$, and $\mathrm{u}$ and $\mathrm{v}$ are adjacent to a common vertex of $\mathrm{V}-\left\{\mathrm{v}_{1}\right\}$, then the two paths have lengths 2 , and 3 , therefore $\mathrm{d}_{2}^{*}\left(\mathrm{u}, \mathrm{v} \mid \mathrm{W}_{\mathrm{m}}^{\mathrm{c}}\right)=3$, and the number of such pairs $\{\mathrm{u}, \mathrm{v}\}$ is $2(\mathrm{~m}-1)$.

(d) If $\mathrm{v} \in \mathrm{V}-\left\{\mathrm{v}_{1}\right\}$, and $\mathrm{u}$ and $\mathrm{v}$ are neither adjacent nor adjacent to a common vertex of $\mathrm{V}-\left\{\mathrm{v}_{1}\right\}$, then the two paths have lengths 3, and $\mathrm{d}\left(\mathrm{u}, \mathrm{v} \mid \mathrm{W}_{\mathrm{m}}^{\mathrm{c}}-\left\{\mathrm{v}_{1}\right\}\right)$. Since, $3 \leq \mathrm{d}\left(\mathrm{u}, \mathrm{v} \mid \mathrm{W}_{\mathrm{m}}^{\mathrm{c}}-\left\{\mathrm{v}_{1}\right\}\right) \leq\left\lfloor\frac{\mathrm{m}}{2}\right\rfloor$, then $\mathrm{d}_{2}^{*}\left(\mathrm{u}, \mathrm{v} \mid \mathrm{W}_{\mathrm{m}}^{\mathrm{c}}\right)=\mathrm{d}\left(\mathrm{u}, \mathrm{v} \mid \mathrm{W}_{\mathrm{m}}^{\mathrm{c}}-\left\{\mathrm{v}_{1}\right\}\right)$.

Let $\mathrm{d}\left(\mathrm{u}, \mathrm{v} \mid \mathrm{W}_{\mathrm{m}}^{\mathrm{c}}-\left\{\mathrm{v}_{1}\right\}\right)=\mathrm{k}$, for all $3 \leq \mathrm{k} \leq\left\lfloor\frac{\mathrm{m}}{2}\right\rfloor$, then the number of pairs $\{\mathrm{u}, \mathrm{v}\}$ such that $\mathrm{d}_{2}^{*}\left(\mathrm{v}, \mathrm{u} \mid \mathrm{W}_{\mathrm{m}}^{\mathrm{c}}\right)=\mathrm{k}$, for all $3 \leq \mathrm{k} \leq\left\lfloor\frac{\mathrm{m}}{2}\right\rfloor$ is $2(\mathrm{~m}-1)$, except if $\mathrm{m}$ is even, in which the number of $\{\mathrm{u}, \mathrm{v}\}$ such that $\mathrm{d}_{2}^{*}\left(\mathrm{v}, \mathrm{u} \mid \mathrm{W}_{\mathrm{m}}^{\mathrm{c}}\right)=\frac{\mathrm{m}}{2}$, is $(\mathrm{m}-1)$.

Thus, 
$H_{2}^{*}\left(R, W_{m}^{c} ; x\right)=(m-1) x^{2}+2(m-1) x^{3}+2(m-1)\left[\begin{array}{l}\frac{m-1}{2} \\ \sum_{i=2}^{i} x^{i}, \text { if } m \text { is odd }, \\ \frac{m}{2}-1 \\ \sum_{i=2}^{i} x^{i}+\frac{1}{2} x^{\frac{m}{2}}, \text { if } m \text { is even },\end{array}\right.$

where $\mathrm{R}=\{(\mathrm{u}, \mathrm{v}): \mathrm{u} \in \mathrm{U}, \mathrm{v} \in \mathrm{V}\}$, such that $\mathrm{d}_{2}^{*}\left(\mathrm{u}, \mathrm{v} \mid \mathrm{W}_{\mathrm{m}}^{\mathrm{c}}\right)=\mathrm{k}$, for all $2 \leq \mathrm{k} \leq\left\lfloor\frac{\mathrm{m}}{2}\right\rfloor$.

From $\mathrm{H}_{2}^{*}\left(\mathrm{~W}_{\mathrm{m}}^{\mathrm{c}} ; \mathrm{x}\right)=\mathrm{H}_{2}^{*}\left(\tilde{\mathrm{U}}, \mathrm{W}_{\mathrm{m}}^{\mathrm{c}} ; \mathrm{x}\right)+\mathrm{H}_{2}^{*}\left(\tilde{\mathrm{V}}, \mathrm{W}_{\mathrm{m}}^{\mathrm{c}} ; \mathrm{x}\right)+\mathrm{H}_{2}^{*}\left(\mathrm{R}, \mathrm{W}_{\mathrm{m}}^{\mathrm{c}} ; \mathrm{x}\right)$, we get (4.3.1).

We notice, from (4.3.1), that $\mathrm{H}_{2}^{*}\left(\mathrm{~W}_{\mathrm{m}}^{\mathrm{c}} ; \mathrm{x}\right)$ is 3-semi-palindromic for $\mathrm{m} \geq 16$.

\section{Remark:}

- $\mathrm{H}_{2}^{*}\left(\mathrm{~W}_{4}^{\mathrm{c}} ; \mathrm{x}\right)=18 \mathrm{x}^{2}+2 \mathrm{x}^{3}$.

- $\mathrm{H}_{2}^{*}\left(\mathrm{~W}_{5}^{\mathrm{c}} ; \mathrm{x}\right)=22 \mathrm{x}^{2}+10 \mathrm{x}^{3}+4 \mathrm{x}^{4}$.

- $\mathrm{H}_{2}^{*}\left(\mathrm{~W}_{6}^{\mathrm{c}} ; \mathrm{x}\right)=30 \mathrm{x}^{2}+15 \mathrm{x}^{3}+10 \mathrm{x}^{4}$.

- $\mathrm{H}_{2}^{*}\left(\mathrm{~W}_{7}^{\mathrm{c}} ; \mathrm{x}\right)=36 \mathrm{x}^{2}+27 \mathrm{x}^{3}+15 \mathrm{x}^{4}$.

Corollary 4.3.2: For $m \geq 6$,

(a) $\mathrm{W}_{2}^{*}\left(\mathrm{~W}_{\mathrm{m}}^{\mathrm{c}}\right)=(\mathrm{m}-1)\left(\mathrm{m}^{2}+22\right) / 2$.

(b) $\mu_{2}^{*}\left(\mathrm{~W}_{\mathrm{m}}^{\mathrm{c}}\right)=\left(\mathrm{m}^{2}+22\right) /(4 \mathrm{~m}-2)$.

Notice that $\mathrm{W}_{2}^{*}\left(\mathrm{~W}_{4}^{\mathrm{c}}\right)=42, \mathrm{~W}_{2}^{*}\left(\mathrm{~W}_{5}^{\mathrm{c}}\right)=90, \mu_{2}^{*}\left(\mathrm{~W}_{4}^{\mathrm{c}}\right)=2$ and $\mu_{2}^{*}\left(\mathrm{~W}_{5}^{\mathrm{c}}\right)=2.5$.

Corollary 4.3.3: For $\mathrm{m} \geq 4, \mu_{2}^{*}\left(\mathrm{~W}_{\mathrm{m}}^{\mathrm{c}}\right) \leq \frac{\mathrm{m}+5}{4}, \mathrm{~m} \geq 4$.

\subsection{Cog Cycles $C_{m}^{c}$ :}

Let $\mathrm{C}_{\mathrm{m}}=\mathrm{v}_{1}, \mathrm{v}_{2}, \ldots, \mathrm{v}_{\mathrm{m}}, \mathrm{v}_{1}$ be a cycle of order $\mathrm{m}$. The cog cycle $\mathrm{C}_{\mathrm{m}}^{\mathrm{c}}, \mathrm{m} \geq 3$, is obtained from $\mathrm{C}_{\mathrm{m}}$ by adding $\mathrm{m}$ new vertices $\mathrm{u}_{1}, \mathrm{u}_{2}, \ldots, \mathrm{u}_{\mathrm{m}}$, and edges $\left\{\mathrm{u}_{\mathrm{i}} \mathrm{v}_{\mathrm{i}}, \mathrm{u}_{\mathrm{i}} \mathrm{v}_{\mathrm{i}+1}: \mathrm{i}=1,2, \ldots, \mathrm{m}\right\} ; \mathrm{v}_{\mathrm{m}+1}=\mathrm{v}_{\mathrm{m}}$ [8], as shown in Fig.4.4.1.

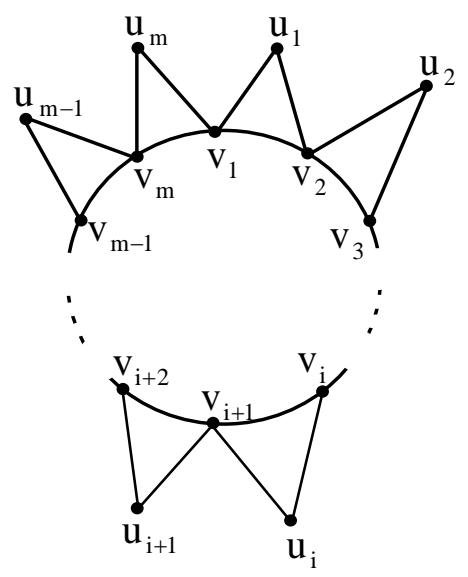

Fig. 4.4.1. $C_{m}^{c}$ 
It is clear that $\mathrm{p}\left(\mathrm{C}_{\mathrm{m}}^{\mathrm{c}}\right)=2 \mathrm{~m}, \mathrm{q}\left(\mathrm{C}_{\mathrm{m}}^{\mathrm{c}}\right)=3 \mathrm{~m}, \mathrm{w}=2, \quad \delta_{2}^{*}\left(\mathrm{C}_{\mathrm{m}}^{\mathrm{c}}\right)=\mathrm{m}$, and $\mathrm{m}_{\mathrm{w}}\left(\mathrm{C}_{\mathrm{m}}^{\mathrm{c}}\right)=2$.

Theorem 4.4.1: For $m \geq 7$, then

$$
\begin{aligned}
& \mathrm{H}_{2}^{*}\left(\mathrm{C}_{\mathrm{m}}^{\mathrm{c}} ; \mathrm{x}\right)=3 \mathrm{mx} \mathrm{x}^{2}+3 \mathrm{mx} \mathrm{x}^{\mathrm{m}-1}+\mathrm{mx} \mathrm{x}^{\mathrm{m}} \\
&+4 \mathrm{~m}\left[\begin{array}{l}
\sum_{\mathrm{i}=2}^{\frac{\mathrm{m}-3}{2}} \mathrm{x}^{\mathrm{m}-\mathrm{i}}+\frac{1}{2} \mathrm{x}^{\frac{\mathrm{m}+1}{2}}, \text { if } \mathrm{m} \text { is odd }, \\
\sum_{\mathrm{i}=2}^{\frac{\mathrm{m}}{2}} \mathrm{x}^{\mathrm{m}-\mathrm{i}}+\frac{7}{8} \mathrm{x}^{\frac{\mathrm{m}}{2}+1}+\frac{1}{8} \mathrm{x}^{\frac{\mathrm{m}}{2}}, \text { if } \mathrm{m} \text { is even } .
\end{array}\right.
\end{aligned}
$$

Proof: Let $\mathrm{V}=\left\{\mathrm{v}_{1}, \mathrm{v}_{2}, \ldots, \mathrm{v}_{\mathrm{m}}\right\}$, and $\mathrm{U}=\left\{\mathrm{u}_{1}, \mathrm{u}_{2}, \ldots, \mathrm{u}_{\mathrm{m}}\right\}$, then there are three cases to prove (4.4.1).

Case (1): If $u, u^{\prime} \in U, u \neq u^{\prime}$, then there are two internally disjoint paths between $u$ and $\mathrm{u}^{\prime}$ having length $\mathrm{d}\left(\mathrm{u}, \mathrm{u}^{\prime} \mid \mathrm{C}_{\mathrm{m}}^{\mathrm{c}}\right)$ and $(\mathrm{m}+2)-\mathrm{d}\left(\mathrm{u}, \mathrm{u}^{\prime} \mid \mathrm{C}_{\mathrm{m}}^{\mathrm{c}}\right)$.

Since $2 \leq \mathrm{d}\left(\mathrm{u}, \mathrm{u}^{\prime} \mid \mathrm{C}_{\mathrm{m}}^{\mathrm{c}}\right) \leq\left\lfloor\frac{\mathrm{m}+2}{2}\right\rfloor$, then $\mathrm{d}_{2}^{*}\left(\mathrm{u}, \mathrm{u}^{\prime} \mid \mathrm{C}_{\mathrm{m}}^{\mathrm{c}}\right)=(\mathrm{m}+2)-\mathrm{d}\left(\mathrm{u}, \mathrm{u}^{\prime} \mid \mathrm{C}_{\mathrm{m}}^{\mathrm{c}}\right)$.

Let $\mathrm{d}\left(\mathrm{u}, \mathrm{u}^{\prime} \mid \mathrm{C}_{\mathrm{m}}^{\mathrm{c}}\right)=\mathrm{k}$, for all $2 \leq \mathrm{k} \leq\left\lfloor\frac{\mathrm{m}+2}{2}\right\rfloor$, then the number of pairs $\left\{\mathrm{u}, \mathrm{u}^{\prime}\right\}$ such that $d_{2}^{*}\left(u, u^{\prime} \mid C_{m}^{c}\right)=(m+2)-k$ is $m$, except if $m$ is even, in which the number of $\left\{u, u^{\prime}\right\}$ such that

$\mathrm{d}_{2}^{*}\left(\mathrm{u}, \mathrm{u}^{\prime} \mid \mathrm{C}_{\mathrm{m}}^{\mathrm{c}}\right)=\frac{\mathrm{m}+2}{2}$, is $\frac{\mathrm{m}}{2}$.

Hence,

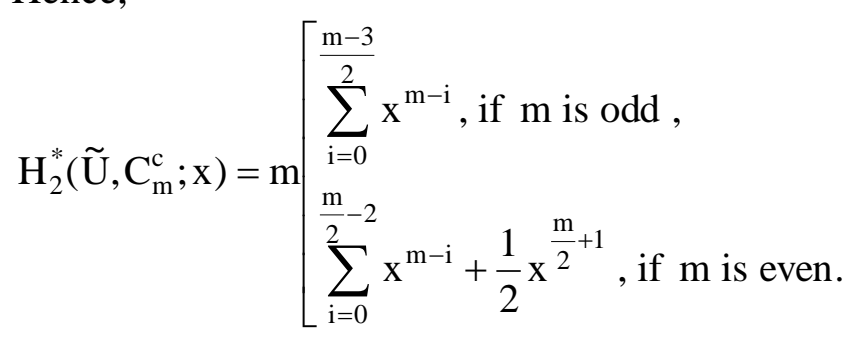

Case (2): If $v, v^{\prime} \in V, v \neq v^{\prime}$, then either $v v^{\prime} \in E\left(C_{m}^{c}\right)$, or $v v^{\prime} \notin E\left(C_{m}^{c}\right)$.

If $\mathrm{vv}^{\prime} \in \mathrm{E}\left(\mathrm{C}_{\mathrm{m}}^{\mathrm{c}}\right)$, then there are three internally disjoint paths between $\mathrm{v}$ and $\mathrm{v}^{\prime}$, having lengths 1,2 , and $\mathrm{m}-1$, thus

$\mathrm{d}_{2}^{*}\left(\mathrm{v}, \mathrm{v}^{\prime} \mid \mathrm{C}_{\mathrm{m}}^{\mathrm{c}}\right)=\min [\max \{1,2\}, \max \{1, \mathrm{~m}-1\}, \max \{2, \mathrm{~m}-1\}]=2$.

The number of pairs $\left\{\mathrm{v}, \mathrm{v}^{\prime}\right\}$, such that $\mathrm{d}\left(\mathrm{v}, \mathrm{v}^{\prime} \mid \mathrm{C}_{\mathrm{m}}^{\mathrm{c}}\right)=2, \mathrm{vv}^{\prime} \in \mathrm{E}\left(\mathrm{C}_{\mathrm{m}}^{\mathrm{c}}\right)$ is $\mathrm{m}$.

Now, if $\mathrm{vv}^{\prime} \notin \mathrm{E}\left(\mathrm{C}_{\mathrm{m}}^{\mathrm{c}}\right)$, then there are two internally disjoint paths between $\mathrm{v}$ and $\mathrm{v}^{\prime}$, having lengths $\mathrm{d}\left(\mathrm{v}, \mathrm{v}^{\prime} \mid \mathrm{C}_{\mathrm{m}}^{\mathrm{c}}\right)$, and $\mathrm{m}-\mathrm{d}\left(\mathrm{v}, \mathrm{v}^{\prime} \mid \mathrm{C}_{\mathrm{m}}^{\mathrm{c}}\right)$.

Since $2 \leq \mathrm{d}\left(\mathrm{u}, \mathrm{v} \mid \mathrm{C}_{\mathrm{m}}^{\mathrm{c}}\right) \leq\left\lfloor\frac{\mathrm{m}}{2}\right\rfloor$, then 
$\mathrm{d}_{2}^{*}\left(\mathrm{v}, \mathrm{v}^{\prime} \mid \mathrm{C}_{\mathrm{m}}^{\mathrm{c}}\right)=\mathrm{m}-\mathrm{d}\left(\mathrm{v}, \mathrm{v}^{\prime} \mid \mathrm{C}_{\mathrm{m}}^{\mathrm{c}}\right)=\mathrm{m}-\mathrm{d}\left(\mathrm{v}, \mathrm{v}^{\prime} \mid \mathrm{C}_{\mathrm{m}}\right)=\mathrm{d}_{2}^{*}\left(\mathrm{v}, \mathrm{v}^{\prime} \mid \mathrm{C}_{\mathrm{m}}\right)$.

Hence, from this case and (3.3), we have

$$
\begin{aligned}
\mathrm{H}_{2}^{*}\left(\tilde{\mathrm{V}}, \mathrm{C}_{\mathrm{m}}^{\mathrm{c}} ; \mathrm{x}\right) & =\mathrm{H}_{2}^{*}\left(\mathrm{C}_{\mathrm{m}} ; \mathrm{x}\right)-\mathrm{mx} \mathrm{x}^{\mathrm{m}-1}+\mathrm{mx}^{2} \\
& =\mathrm{m}\left[\begin{array}{l}
\frac{\mathrm{m}-1}{2} \\
\sum_{\mathrm{i}=2}^{2} \mathrm{x}^{\mathrm{m}-\mathrm{i}}+\mathrm{x}^{2}, \text { if } \mathrm{m} \text { is odd }, \\
\sum_{\mathrm{i}=2}^{\frac{\mathrm{m}}{2}-1} \mathrm{x}^{\mathrm{m}-\mathrm{i}}+\frac{1}{2} \mathrm{x}^{\frac{\mathrm{m}}{2}}+\mathrm{x}^{2}, \text { if } \mathrm{m} \text { is even. }
\end{array}\right.
\end{aligned}
$$

Case (3): If $u \in U$, and $v \in V$, then either $u v \in E\left(C_{m}^{c}\right)$, or $u v \notin E\left(C_{m}^{c}\right)$.

If $\mathrm{uv} \in \mathrm{E}\left(\mathrm{C}_{\mathrm{m}}^{\mathrm{c}}\right)$, then there are two internally disjoint paths between the vertices $\mathrm{u}$ and $\mathrm{v}$ of length 1 and 2 , then $\mathrm{d}_{2}^{*}\left(\mathrm{u}, \mathrm{v} \mid \mathrm{C}_{\mathrm{m}}^{\mathrm{c}}\right)=2$.

It is clear that the number of pairs $\{u, v\}$, such that $d_{2}^{*}\left(u, v \mid C_{m}^{c}\right)=2, u v \in E\left(C_{m}^{c}\right)$ is $2 \mathrm{~m}$.

Now, if $u v \notin E\left(C_{m}^{c}\right)$, then there are two internally disjoint paths between the vertices $u$ and $\mathrm{v}$ having length $\mathrm{d}\left(\mathrm{u}, \mathrm{v} \mid \mathrm{C}_{\mathrm{m}}^{\mathrm{c}}\right)$, and $(\mathrm{m}+1)-\mathrm{d}\left(\mathrm{u}, \mathrm{v} \mid \mathrm{C}_{\mathrm{m}}^{\mathrm{c}}\right)$.

Since $2 \leq \mathrm{d}\left(\mathrm{u}, \mathrm{v} \mid \mathrm{C}_{\mathrm{m}}^{\mathrm{c}}\right) \leq\left\lfloor\frac{\mathrm{m}+1}{2}\right\rfloor$, then $\mathrm{d}_{2}^{*}\left(\mathrm{u}, \mathrm{v} \mid \mathrm{C}_{\mathrm{m}}^{\mathrm{c}}\right)=(\mathrm{m}+1)-\mathrm{d}\left(\mathrm{u}, \mathrm{v} \mid \mathrm{C}_{\mathrm{m}}^{\mathrm{c}}\right)$.

Let $d\left(u, v \mid C_{m}^{c}\right)=k$, for all $2 \leq k \leq\left\lfloor\frac{m+1}{2}\right\rfloor$, then the number of pairs $\{u, v\}$ such that $\mathrm{d}_{2}^{*}\left(\mathrm{u}, \mathrm{v} \mid \mathrm{C}_{\mathrm{m}}^{\mathrm{c}}\right)=(\mathrm{m}+1)-\mathrm{k}$ is $2 \mathrm{~m}$, except if $\mathrm{m}$ is odd, in which the number of $\{\mathrm{u}, \mathrm{v}\}$ such that $\mathrm{d}_{2}^{*}\left(\mathrm{u}, \mathrm{v} \mid \mathrm{C}_{\mathrm{m}}^{\mathrm{c}}\right)=\frac{\mathrm{m}+1}{2}$, is $\mathrm{m}$.

Thus, from this case, we get

$$
H_{2}^{*}\left(R, C_{m}^{c} ; x\right)=2 m\left[\begin{array}{l}
\sum_{i=1}^{\frac{m-3}{2}} x^{m-i}+\frac{1}{2} x^{\frac{m+1}{2}}+x^{2}, \text { if } m \text { is odd }, \\
\sum_{i=1}^{\frac{m}{2}-1} x^{m-i}+x^{2}, \text { if } m \text { is even, }
\end{array}\right.
$$

where $\mathrm{R}=\{(\mathrm{u}, \mathrm{v}): \mathrm{u} \in \mathrm{U}, \mathrm{v} \in \mathrm{V}\}$.

From $\mathrm{H}_{2}^{*}\left(\mathrm{C}_{\mathrm{m}}^{\mathrm{c}} ; \mathrm{x}\right)=\mathrm{H}_{2}^{*}\left(\tilde{\mathrm{U}}, \mathrm{C}_{\mathrm{m}}^{\mathrm{c}} ; \mathrm{x}\right)+\mathrm{H}_{2}^{*}\left(\tilde{\mathrm{V}}, \mathrm{C}_{\mathrm{m}}^{\mathrm{c}} ; \mathrm{x}\right)+\mathrm{H}_{2}^{*}\left(\mathrm{R}, \mathrm{C}_{\mathrm{m}}^{\mathrm{c}} ; \mathrm{x}\right)$, we get (5.7.1).

\section{Remark:}

- $\mathrm{H}_{2}^{*}\left(\mathrm{C}_{3}^{\mathrm{c}} ; \mathrm{x}\right)=12 \mathrm{x}^{2}+3 \mathrm{x}^{3}$.

- $\mathrm{H}_{2}^{*}\left(\mathrm{C}_{4}^{\mathrm{c}} ; \mathrm{x}\right)=14 \mathrm{x}^{2}+10 \mathrm{x}^{3}+4 \mathrm{x}^{4}$.

- $\mathrm{H}_{2}^{*}\left(\mathrm{C}_{5}^{\mathrm{c}} ; \mathrm{x}\right)=15 \mathrm{x}^{2}+10 \mathrm{x}^{3}+15 \mathrm{x}^{4}+5 \mathrm{x}^{5}$

- $\mathrm{H}_{2}^{*}\left(\mathrm{C}_{6}^{\mathrm{c}} ; \mathrm{x}\right)=18 \mathrm{x}^{2}+3 \mathrm{x}^{3}+21 \mathrm{x}^{4}+18 \mathrm{x}^{5}+6 \mathrm{x}^{6}$.

Corollary 4.4.2: If $C_{m}^{c}, m \geq 3$ be a cog-cycle graph of order $2 m$, then 
(a) $\mathrm{W}_{2}^{*}\left(\mathrm{C}_{\mathrm{m}}^{\mathrm{c}}\right)=\mathrm{m}\left(3 \mathrm{~m}^{2}-6 \mathrm{~m}+13\right) / 2$.

(b) $\mu_{2}^{*}\left(C_{m}^{c}\right)=\left(3 m^{2}-6 m+13\right) /(4 m-2)$.

(c) $\mu_{2}^{*}\left(C_{m}^{c}\right) \leq \frac{3 m}{4}$.

\section{REFERENCES}

[1] Ali, A.M.; (2005), Wiener Polynomials of Generalized Distance in Graphs, M.Sc. Thesis, Mosul University, Mosul.

[2] Aziz, A.S.; (2006), The Width Distance and w-Wiener Polynomials of a graph, M.Sc. Thesis, Mosul University, Mosul.

[3] Chartrand, G. and Lesniak, L.; (1986). Graphs and Digraphs, $2^{\text {nd }}$ ed.,Wadsworth and Brooks / Cole, California.

[4] Gutman, I.; (1993), "Some properties of the Wiener polynomial"; Graph Theory Notes of New York; XXV. The New York Academy of Sciences 13-17.

[5] Heaning, M.A.; Oellermann, O.R. and Swart, H.C.; (1990), "On the Steiner radius and Steiner diameter of a graph". Ars Comb., 29c, 13-19.

[6] Hsu ,D.F.; (1994). "On Container Width and Length in Graphs, Groups, and Networks", IEICE Transactions on Fundamentals of Electronics communications and computer sciences", Vol. E77-A, No.4, pp.668-680.

[7] Sagan, B.E., Y.N. Yeh and P. Zhang; (1996), "The wiener polynomial of a graph"; International J. Qutman Chem.60, No.5, 959-969. 